\title{
A Linguística Construtural: um capítulo da HISTÓRIA DA LINGUÍSTICA NO BRASIL
}

\author{
Constructural Linguistics: a chapter in the \\ history of linguistics in Brazil
}

\author{
José Borges Neto*
}

\begin{abstract}
RESUMO
A Linguística Construtural (LC) é uma teoria linguística, de extração estruturalista, desenvolvida nos anos sessenta e setenta do século XX pelos professores Eurico Back e Geraldo Mattos. A base da LC é Tagmêmica de Kenneth Pike, enriquecida com reflexões oriundas do estruturalismo europeu. No entanto, a LC foi recebida friamente pela comunidade científica, embora se reconhecesse o mérito da sua ousadia e sua contribuição descritiva para o português. Talvez uma das suas características que tenha contribuído para que a comunidade dos linguistas a ignorasse foi a terminologia, já que seus mentores procuraram criar termos novos para noções novas e procuraram definir cuidadosamente usos novos de termos emprestados. Há que se notar, contudo, que a LC se apresentou não apenas como um projeto destinado a revolucionar o tratamento dos fatos linguísticos, olhando-os de um novo ponto de vista, mas também como um projeto que sempre manteve o olhar do professor, interessado, portanto, em obter igualmente uma revolução no ensino do português como língua materna.
\end{abstract}

Palavras-chave: Linguística Construtural; ensino de português; história da linguística no Brasil.

\begin{abstract}
Constructural Linguistics (CL) is a linguistic theory, which stems from structuralist roots, developed in the sixties and

* UFPR/UNIOESTE/CNPq
\end{abstract}


seventies of the twentieth century by Professors Eurico Back and Geraldo Mattos. The basis of the CL is Kenneth Pike's Tagmemics, enriched with developments of aspects of European structuralism. Nevertheless, CL was not well received by the general scientific community at the time, although both the merits of its boldness and its contribution to the description of Portuguese were acknowledged. Perhaps one of the reasons why linguists ignored CL was its terminology, as their mentors sought to create new terms for new ideas and sought to carefully define new uses of borrowed terms. It should be noted, however, that CL presented itself not only as a project to revolutionize the treatment of linguistic facts, looking at them from a new point of view, but also as a project that always took the teacher's perspective as well, therefore, aiming at a revolution in teaching Portuguese as a mother tongue.

Keywords: Constructural Linguistics; Portuguese teaching; history of Linguistics in Brazil.

\section{Antecedentes ${ }^{1}$}

Darcy Ribeiro, fundador e primeiro reitor da Universidade de Brasília, teve parte de sua formação feita em universidades norte-americanas. Impressionado com o fato de que em praticamente todas essas universidades havia um Departamento de Linguística, resolveu que na Universidade de Brasília isso também aconteceria. Para constituir esse primeiro Departamento de Linguística no Brasil, foi buscar linguistas nas universidades brasileiras. No início dos anos 60 do século XX, em muito poucos lugares fazia-se, paralelamente aos estudos de gramática, uma linguística que se assemelhasse minimamente à linguística europeia ou norte-americana. A disciplina "linguística" estava ausente na imensa maioria dos cursos de Letras do Brasil e docentes capazes de conduzir a disciplina eram extremamente escassos. Havia estudos que poderiam se chamar de "linguística" no Rio de Janeiro, a partir do trabalho de Joaquim Mattoso Camara Jr., em São Paulo, graças ao trabalho de Henrique Teodoro Maurer Jr., na Bahia, com Nelson Rossi, no Paraná, a partir do trabalho de Rosário Farâni Mansur Guérios e de Aryon Rodrigues e, talvez, em mais um ou dois lugares.

Antes de 1962, no entanto, a disciplina "Linguística" só era lecionada, por Mattoso Camara Jr., na Faculdade Nacional de Filosofia, no Rio de Janeiro, e por Aryon Dal'Igna Rodrigues, em Curitiba, na Universidade Federal do Paraná. Carlos Eduardo Falcão Uchôa nos conta essa história da seguinte maneira:

1 Agradeço a um parecerista anônimo as sugestões - todas pertinentes - que me levaram a fazer alguns acréscimos e modificações no texto original. 
No ensino universitário, Mattoso Camara principiou as suas atividades, em 1938, como professor de Lingüistica e de Latim na antiga Universidade do Distrito Federal. No início de 1939, é extinta a Universidade do Distrito Federal e, em seu lugar, instalou-se no mesmo ano, a Faculdade Nacional de Filosofia da Universidade do Brasil, em cujo currículo de Letras não se incluíra a Lingüística. Só a partir de 1948 é que Mattoso Camara é convidado para professor regente de Lingüistica na Faculdade Nacional de Filosofia, tornando-se, então, o pioneiro do ensino regular e ininterrupto de Lingüística no Brasil, tendo já, em 1942, sido responsável por um curso de extensão universitária, sobre Lingüistica Geral, nesta mesma Faculdade. Durante muitos anos, este ficou sendo o único de Lingüística ministrado no Brasil, pois só em dezembro de 19620 Conselho Federal de Educação estabeleceu que toda escola superior de Letras deveria incluir obrigatoriamente o ensino de Lingüistica nos seus currículos, embora já em 1960 a Universidade do Paraná tenha passado a oferecer curso de Lingüística em sua programação $e$, no ano letivo de 1962, a então recém-criada Universidade de Brasília tenha igualmente colocado a Lingüistica na sua organização curricular (UCHÔA, 1975, p. VIII).

No início dos anos sessenta, então, a Universidade Federal do Paraná destacava-se no cenário nacional por formar seus estudantes em contato com algumas teorias linguísticas europeias e norte-americanas, por ter criado, já em 1953, o Círculo Linguístico de Curitiba, nos moldes do Círculo Linguístico de Nova Iorque, por manter em circulação a Revista Letras (criada em 1953, como porta-voz do Círculo e existente até hoje: a revista mais antiga da área em circulação, portanto), que publicava trabalhos dos principais linguistas e gramáticos brasileiros (entre os quais Mattoso Câmara Jr.), e por contar em seu corpo docente com o Prof. Aryon Dal'Igna Rodrigues, o primeiro Doutor em Linguística do Brasil com título obtido em curso de doutoramento regular. Além disso, a Universidade Federal do Paraná não vivia o "clima de guerra" entre linguistas e filólogos (e/ou gramáticos) que se via no Rio de Janeiro. O olhar de Darcy Ribeiro, na tarefa de criar um departamento de linguística na Universidade de Brasília, não podia ignorar a universidade paranaense.

Mattoso Camara, a escolha primeira, por razões de ordem familiar, não pode aceitar o convite de Darcy Ribeiro que, então, encarregou Aryon Rodrigues de criar, na Universidade de Brasília, o primeiro Departamento de Linguística de uma universidade brasileira.

o passo seguinte de Darcy Ribeiro, já como Ministro da Educação e da Cultura do governo de João Goulart, foi tornar obrigatória em todos os cursos de Letras a disciplina "linguística". Atitude temerária, uma vez que não havia pessoal qualificado para ministrar a disciplina na grande maioria 
das instituições. Como forma de solucionar o problema, criou-se - na Universidade de Brasília - cursos de especialização em Linguística voltados à formação emergencial de docentes de linguística. Esses cursos, ministrados em colaboração com o Summer Institute of Linguistics (SIL), formaram uma primeira geração de linguistas competentes numa das versões do estruturalismo americano, denominada Tagmêmica (Tagmemics), reconhecida como um conjunto de procedimentos analíticos bastante úteis para a descrição de línguas ágrafas e/ou pouco conhecidas, como as línguas indígenas brasileiras. Parece claro que essa escolha deveu-se não só aos interesses de Aryon Rodrigues, que já se destacava como estudioso das línguas indígenas brasileiras, como à perspectiva que Darcy Ribeiro - antropólogo de formação - tinha quanto aos objetivos mais imediatos do ensino de linguística no cenário brasileiro.

Apesar de já haver - como vimos - estudos linguísticos na Universidade Federal do Paraná, esta universidade encaminhou o Prof. Eurico Back - linguista de formação histórico-comparativa, autor de tese sobre a evolução das vogais do latim ao português - para os cursos de especialização na UnB.

Em seu retorno a Curitiba, Back foi chamado à presença do Prof. Mansur Guérios - então catedrático de Língua Portuguesa - que lhe fez uma provocação: diante do esgotamento descritivo e explicativo da gramática tradicional e diante da baixa qualidade das gramáticas escolares, era necessária a elaboração de uma gramática do português, no quadro teórico da Tagmêmica, não só como atividade de pesquisa linguística, mas também como base para novas gramáticas escolares. Back, então, convidou o Prof. Geraldo Mattos Gomes dos Santos (mais conhecido apenas como Geraldo Mattos) - professor da Universidade Católica do Paraná e do Colégio Militar de Curitiba - para auxiliá-lo na tarefa e, juntos, deram início à tarefa de construir uma gramática estrutural do português, nos moldes tagmêmicos.

Num certo momento da tarefa, diante das inúmeras modificações teóricas que se faziam necessárias para uma adequada descrição dos fatos do português, os dois professores acreditaram já terem em mãos uma teoria suficientemente distinta da tagmêmica para que recebesse um novo nome. Depois de algumas discussões, resolveram chamar a "nova teoria" pelo nome sugerido por Geraldo Mattos: Gramática Construtural.

\section{OS PERSONAGENS}

Eurico Back (nascido em Forquilhinha/SC, em 24 de janeiro de 1923, e falecido, também em Forquilhinha, em 26 de setembro de 2003) era 
um competentíssimo professor de português - com passagens pelo ensino oficial do Estado do Paraná (foi professor e diretor do Colégio Estadual do Paraná), pelo Colégio Militar de Curitiba -, e professor de Linguística na Universidade Católica do Paraná e na Universidade Federal do Paraná (depois de aposentado na UFPR, lecionou Linguística na UDESC, em Criciúma/SC). Obteve a Livre-Docência em Linguística na UFPR, com tese intitulada Fonêmica Diacrônica Latino-Portuguesa, em 1964. Participou, como aluno, da segunda turma do Curso de Especialização promovido pela UnB, ministrado por Aryon Rodrigues e por professores do SIL.

Geraldo Mattos (nascido em Teresópolis/RJ em 28 de junho de 1931) era professor de português do Colégio Militar de Curitiba e professor de Língua Portuguesa na Universidade Católica do Paraná (a partir de 1979, lecionou Linguística e Língua Portuguesa na UFPR). Obteve a Livre-Docência em Filologia na UFPR, em 1967, com tese sobre as cantigas de Ayras Nunes, poeta trovador do séc. XIV.

$O$ projeto de Back \& Mattos foi financiado pela Universidade Católica do Paraná (hoje, PUC-PR), que lhes concedeu uma pequena sala como sede do projeto e vinte horas semanais para a pesquisa, e teve quase toda a sua produção publicada pela Editora FTD. Tanto a PUC-PR quanto a FTD eram (são, ainda) mantidas pelos Irmãos Maristas, o que os torna os principais apoiadores do projeto.

Back \& Mattos, enquanto professores (de Linguística e de Língua Portuguesa, respectivamente) na Universidade Católica, conseguiram agregar junto de si um conjunto de jovens estudantes (posteriormente, todos, professores na PUC-PR ${ }^{2}$ ) que ajudaram no desenvolvimento do projeto. Orlando Bogo, David Mandryk, Basílio Agostini, José Luiz da Veiga Mercer, Carlos Alberto Faraco e José Borges Neto encontravam-se entre eles.

\section{A Linguística Construtural: suas origens}

A Linguística Construtural (LC) é uma teoria linguística, de extração estruturalista, desenvolvida nos anos sessenta e setenta do século XX pelos professores Eurico Back e Geraldo Mattos. A base da LC é, como dissemos acima, a Tagmêmica de Kenneth Pike, enriquecida com reflexões oriundas do estruturalismo europeu (principalmente da Glossemática de Louis Hjelmslev, que é sempre tratada por Back e Mattos como "Gramática Imanente”) e da gramática tradicional. 
Encontramos, também, algumas referências à "Gramática Transformativa", bem como a presença de alguns termos (como "competence" e "performance", por exemplo), dela oriundos, nos textos de Back e Mattos. Posso garantir, no entanto, que a influência das ideias de Noam Chomsky na LC é praticamente nula. Os autores sempre leram Chomsky de segunda mão e nunca entenderam completamente suas ideias. Talvez - mas isso eu não posso garantir - o único contato dos nossos autores com as ideias da Gramática Gerativa tenha se dado por meio do texto de Mattoso Camara Jr. em que se apresentam algumas das características da teoria de Chomsky (ver CAMARA JR., 1967), entendida como mais uma proposta estruturalista. No fim de 1972, um dos alunos ligados ao projeto (José Borges Neto) foi orientado por Geraldo Mattos a frequentar um curso introdutório de gramática gerativa, que seria ministrado na UFSC nos meses de janeiro e fevereiro de 1973, como parte do VI Instituto Brasileiro de Linguística, promovido pela Abralin, com a alegação de que "precisávamos saber mais sobre esta teoria". As "origens" da LC são descritas, na introdução da Gramática Construtural da Lingua Portuguesa, da seguinte maneira:

Alertados pelo prof. Rosário Farâni Mansur Guérios, em suas aulas na Faculdade, de que era necessário rever as posições da gramática portuguesa e reformular as conclusóes de acordo com os princípios modernos da Lingüística, pusemos mãos à obra; e, honestamente, sem esperança de poder conclui-la um dia. Sabiamos que pontos de vista diferentes condicionam resultados distintos de observação. o nosso maior problema inicial foi a escolha de um modelo de descrição lingüística. A escolha deveria ser feita por um modelo, cujos postulados pudéssemos considerar válidos.

Descartamos imediatamente a Lógica Filosófica: é consenso unânime não mais fundir ou confundir Análise Sintática com Análise Lógica; ninguém duvida de que o sinal lingüístico é convencional $e$ que significantes diferentes podem ter o mesmo significado. Abandonamos também a Gramática Transformativa, os Constituintes Imediatos (a Sintagmática), a Gramática Imanente, por não concordarmos com os seus postulados. O nosso estudo inicial nos levou a considerar a Tagmêmica o melhor modelo. Entretanto, no correr de nossas pesquisas, nem ela nos podia socorrer em todos os instantes e a técnica de Pike e Longacre não resolvia todos os casos. Chegamos a observar todos os elementos da nossa língua e o seu funcionamento. Raciocinando sobre a língua como instrumento de comunicação, partimos da Comunicação (1 $1^{a}$ Parte) e estabelecemos como postulados as relaçóes entre os elementos de um conjunto (Introdução da $3^{a}$ Parte). Surgiu diante de nossos olhos uma nova técnica de descrição lingüística, que denominamos Lingüistica Construtural: o conceito básico é a construtura. Deu-nos a definição de linguagem como código de tríplice construtura. Entretanto, nem 
tudo é novidade: o conceito de relações inspirou-se na Gramática Imanente; as transformações provieram da Gramática Transformativa (embora na língua nem tudo seja transformação e nem toda transformação seja língua); o reconhecimento das funções pela coocorrência ou a sua comutação é resultado da Tagmêmica. Efetivamente, todos os grandes pesquisadores têm parte da verdade; mas nenhuma das técnicas anteriores permitiu o estudo científico completo de uma língua em todos os seus campos: o dos significantes, o semântico e o estilístico.

Esta obra é o resultado de muitos anos de estudos. Não pudemos colocar aqui todas as bases científicas; cremos, porém, que alicerces suficientemente fortes sustentem o nosso trabalho. Não pudemos também aludir a todas as implicações no ensino das línguas (cf. "Genética da Aprendizagem") mas esperamos publicar ainda um livro de Lingüistica Construtural com a teoria correspondente (BACK; MATTOS, 1972 ${ }^{3}$ ).

O "livro" de linguística prometido saiu sob a forma de um Manifesto (BACK; MATTOS, 1973) no primeiro número de uma revista especializada denominada Construtura, que teve 19 números publicados (entre 1973 e 1979). A "Genética da Aprendizagem" se constituiu numa teoria geral da aprendizagem que deu sustentação a uma série de livros didáticos, para todos os níveis do ensino, e a um livro de prática de ensino de língua portuguesa (MATTOS; BACK, 1974). Pretensamente baseada nas ideias de Piaget sobre a aprendizagem, essa teoria é, no entanto, fortemente baseada numa perspectiva behaviorista. Apesar do interesse que o estudo dessas ideias possa vir a ter, não é minha intenção abordá-las aqui.

É interessante observar, desde já, que a proposta de Back e Mattos era vista por eles como mais uma "técnica" de descrição linguística, mais adequada à descrição do português do que as "técnicas" alternativas (Tagmêmica, Glossemática, Gramática Transformacional, etc.).

\section{A Gramática Construtural da Língua Portuguesa}

Sem pretender fazer uma apresentação extensiva, creio que vale a pena uma apresentação geral da principal obra da LC: a Gramática Construtural da Língua Portuguesa (BACK; MATTOS, 1972).

A Gramática consiste em dois volumes (468 páginas e 428 páginas, respectivamente).

3 Essas palavras introdutórias não têm paginação. 
O primeiro volume é dividido em duas partes: Comunicação e Léxica. Na parte reservada à comunicação (42 páginas), os autores apresentam sua concepção de comunicação e delineiam-se as bases comunicativas da teoria construtural. A Léxica reúne o que poderíamos chamar de estudo do significante. Nesta parte da Gramática encontram-se estudos sobre o que tradicionalmente é denominado fonologia, morfologia e sintaxe. O termo "léxica" foi forjado justamente para evitar confusões com as partes tradicionais das gramáticas, já que as distinções entre fonologia, morfologia e sintaxe são borradas pela teoria construtural e novas distinções são propostas.

O processo comunicativo, na visão dos autores, sempre envolve uma solicitação por parte de um emissor e uma satisfação por parte de um receptor. $O$ conjunto solicitação/satisfação vai constituir a cláusula, que é a unidade de análise ${ }^{4}$. A solicitação que interessa para o estudo é a solicitação exteriorizada linguisticamente. A satisfação nem sempre é manifestada linguisticamente (pode ser manifestada por uma ação ou por um simples acolhimento). Podemos, então, ter cláusulas constituídas por dois enunciados (um correspondendo à solicitação e o outro correspondendo à satisfação, como no caso de uma pergunta e sua resposta) ou constituídas por apenas um enunciado, que corresponde à solicitação (como no caso de uma ordem ou de uma afirmação).

\subsection{LÉXICA}

Na parte referente à Léxica, encontramos análises detalhadas de todos os níveis linguísticos reconhecidos pelos autores.

Inicia-se pela cláusula.

A cláusula, como vimos, é constituída por um ou dois enunciados. o enunciado do emissor é obrigatório, enquanto o enunciado do receptor pode estar presente ou não. Curiosamente, os autores lançam mão de uma metáfora para a exposição de suas ideias: a metáfora do sistema solar. Num sistema solar, o sol é obrigatório, mas os planetas não são (podemos ter uma estrela não acompanhada de planetas). Na cláusula, o enunciado do emissor é obrigatório, mas o enunciado do receptor não é. o enunciado do emissor é chamado de sol da cláusula e o enunciado do receptor é um planeta.

Simultaneamente, a cláusula é um alinhamento de sílabas, em ordem fixa.

4 A “cláusula” é um nível de análise original. Sua presença na teoria, bem como a consideração de que este nível é a unidade de análise, é uma das divergências entre a LC e a Tagmêmica. Outra divergência está no escopo dado às noções de fonologia e morfologia, que além de serem redefinidas, estão presentes em todos os níveis de análise (da cláusula ao morfema). 
Assim, a cláusula possui uma estrutura (períodos coesos por uma relação de dependência - o planeta depende do sol, mas o sol não depende do planeta) e uma construção (um alinhamento de sílabas independentes entre si): a cláusula, porque simultaneamente uma estrutura e uma construção, é uma construtura.

Os constituintes imediatos da cláusula (os enunciados do emissor e do receptor, se houver) são chamados de períodos. Os períodos são conjuntos de sentenças. As sentenças são conjuntos de locuções. As locuções são conjuntos de vocábulos. E os vocábulos são conjuntos de morfemas. Esses são os níveis linguísticos.

Em todos os níveis, há um elemento obrigatório - um sol - e elementos facultativos - planetas (há estrutura, portanto). E todos os níveis se manifestam materialmente como alinhamentos de sílabas (construção). Logo, todos os níveis são construturas.

Creio ser interessante exemplificar essas ideias num dos níveis de análise. Vejamos a construtura da sentença.

Por um lado, a sentença é um alinhamento de sílabas. Por exemplo, a sentença "a professora deu o livro ao menino" corresponde, grosso modo, ao seguinte alinhamento de sílabas: /a.pro.fe."so.ra."dew.o."li.vro. aw.me."'ni.no/. A sentença, então, é uma construção.

Por outro lado, a sentença é uma estrutura de locuções. Uma das locuções da sentença será o sol e as outras serão planetas. O sol da sentença é uma locução verbal (locução cujo sol é um verbo) e os planetas são as locuções complementos. $O$ sol da sentença é também chamado de predicado.

Numa sentença como

$\begin{array}{ccc}\text { O menino } & \text { ouviu } & \text { aquele homem. } \\ 1 & 2 & 3\end{array}$

o sol é "ouviu" e os planetas são "o menino" e " aquele homem".

o predicado é assinalado com o número 2 . O sujeito é assinalado com o número 1 e, nas palavras dos autores, "o sujeito é um planeta; portanto, não é de estranhar que haja sentenças sem o sujeito" (BACK; MATTOS, 1972, p. 188). A posição assinalada com o número 3 é a posição do complemento objetivo (ou objeto).

Além do predicado (posição 2), os autores reconhecem os seguintes complementos nas sentenças do português: sujeito (posição 1), objeto (posição 3), dativo (posição 4), genitivo (posição 5), nominativo (posição 6), acusativo (posição 7) e ablativo (posição 8).

Sem entrar em muitos detalhes, vale a pena justificar alguns desses complementos. 
O dativo (4) é quase o objeto indireto da análise sintática tradicional $^{5}$. Veja-se o exemplo abaixo:

A professora deu ao menino o livro de ciências.

$\begin{array}{llll}1 & 2 & 4 & 3\end{array}$

A determinação do valor sintático dos complementos, até onde é possível, é feita por meio de comutações. Por exemplo, será complemento dativo a locução que se deixa substituir por "lhe".

O genitivo (5) é um complemento manifestado por locução iniciada por preposição que não se deixa substituir por locução mínima (de um só vocábulo). Enquanto o dativo pode ser substituído por "lhe" (cf. "A professora deu-lhe o livro de ciências"), o genitivo recusa qualquer substituição. Como no exemplo abaixo:

$\begin{array}{cccc}0 \text { assaltante } & \text { arrependeu } & \text {-se } & \text { do crime. } \\ 1 & 2 & 3 & 5\end{array}$

O nominativo (6) é um complemento manifestado por uma locução adjetiva (que tem um adjetivo como sol). Como no exemplo:

$\begin{array}{ccc}\text { Meu amigo } & \text { é } & \text { estudioso. } \\ 1 & 2 & 6\end{array}$

O acusativo (7) é um complemento que mais ou menos equivale a um predicado secundário (na terminologia atual). Por exemplo (note-se que a posição 1 - posição do sujeito - não está preenchida):

$\begin{array}{ccc}\text { viu } & - \text { a } & \text { séria } \\ 2 & 3 & 7\end{array}$

Os moradores consideravam o engenheiro seu legítimo
1
2
3

representante.

$\begin{array}{ccc}\text { Achei } & \text { os doces } & \text { gostosos. } \\ 2 & 3 & 7\end{array}$

Finalmente, o ablativo (8) é um complemento manifestado por uma locução adverbial, por locução adjetiva facultativa ou por locução substan-

5 Os autores evitam falar em objeto direto e indireto porque existem, na gramática tradicional, objetos diretos preposicionados e objetos indiretos sem preposição.

6 No sentido "Achei gostosos os doces" 
tiva facultativa que não se deixa substituir por nenhuma outra classe de locução. Nos exemplos:

$\begin{array}{ccc}\text { Meu irmão } & \text { vai } & \text { ao cinema. } \\ 1 & 2 & 8 \\ & & \\ \text { Meu pai } & \text { está } & \text { aqui. } \\ 1 & 2 & 8\end{array}$

Os ablativos recebem ainda uma subclassificação (12 subclasses) e podem coocorrer numa mesma sentença ${ }^{7}$. Num exemplo:

$\begin{array}{cccccc}\text { Mário } & \text { foi } & \text { ontem } & \text { com os amigos } & \text { de carro } & \text { para a praia } \\ 1 & 2 & 8 \mathrm{~T} & 8 \mathrm{M} & 8 \mathrm{I} & 8 \mathrm{~L}\end{array}$

Para os autores, há duas classes de sentença na língua portuguesa: orações e frases. A distinção básica está no preenchimento da posição 2 (predicado) com locuções verbais finitas no caso das orações e com locuções verbais de gerúndio (que os autores chamam de subjuntivo), de infinitivo (que os autores chamam de descritivo pessoal), ou de particípio (que os autores chamam de narrativo) no caso das frases. Vimos acima apenas casos de orações.

Como todas as sentenças possuem estrutura (são sistemas coesos de sol e planetas) e construção (materializam-se em alinhamentos de sílabas), as sentenças são construturas.

Fatores prosódicos podem determinar pontos dessa classificação. Por exemplo, se o primeiro exemplo acima for pronunciado com pausa entre a locução substantiva "a professora" e a locução verbal "deu" e com elevação de tom na primeira (o que representaríamos na escrita como "a professora, [ela] deu ao menino o livro de ciências"), a locução "a professora" não mais seria classificada como um constituinte da sentença (o sujeito), mas classificada como constituinte do período (seria uma sentença, portanto, denominada suplemento de condição, e analisada no nível do período). 0 sujeito da sentença seria o "ela”, se explícito, ou teríamos um caso de posição não preenchida (ausência do planeta). Nesse caso, diz-se que a locução "a professora" foi promovida a sentença. O processo de promoção é o inverso do processo de subordinação: na promoção, elemento de nível inferior ocupa posição de nível superior e, na subordinação, elemento de nível superior ocupa posição de nível inferior.

7 Não vou tentar expor essa subclassificação. Os interessados podem procurar na Gramática (p. 237 e seguintes). 
Certamente haveria mais a ver sobre a construtura das sentenças (e de todos os outros níveis de análise; inclusive das "técnicas" usadas para identificar os constituintes imediatos de cada nível), mas a tarefa superaria em muito os limites deste trabalho.

\subsection{SEMÂNTICA}

No segundo volume, os autores tratam de Semântica e Estilística. A parte destinada à semântica ocupa cerca de 250 páginas, restando cerca de 165 para a estilística.

A concepção de significado que norteia a semântica proposta na Gramática é essencialmente idêntica à da Tagmêmica: dado um texto, procura-se associá-lo a uma situação; pela comparação de textos e situações parcialmente semelhantes determinam-se constâncias e oponências de ambos. Com a repetição desse procedimento podemos determinar, com alguma segurança, o significado de um texto.

Embora localize o significado na relação entre expressões e estados de coisas no mundo, essa concepção de significado não é referencial, no sentido clássico do termo; é, antes, "culturalista”, como podemos ver no seguinte trecho:

Como a linguagem é instrumento de cultura e o texto se associa a uma situação da cultura, segue-se a necessidade de estudar a linguagem, surpreendendo um diálogo de dois nativos dentro do ambiente que lhes é próprio, para facilitar ao linguista o trabalho de associar textos e situações e de compará-los, por fim (BACK; MATTOS, 1972, p. 478).

O mecanismo de análise semântica das expressões, como no caso da sintaxe, baseia-se fortemente no entendimento que os autores têm do processo comunicativo. Nas palavras dos autores:

A linguagem se executa dentro da cláusula. Um emissor projeta um contexto (texto e mensagem) para um receptor: o contexto parte do emissor, que é a origem, e atinge o receptor, que é o destino do contexto. O emissor e o receptor representam os limites de um contexto.

$[\ldots]$

Entre um ponto de partida (origem) e um ponto de chegada (destino), evidentemente movimenta-se uma carga: a carga parte da origem (emissor) e alcança um destino (receptor). A carga desloca-se entre dois limites (origem e destino). 
$[\ldots]$

Uma carga que se movimenta entre uma origem e um destino determina o aparecimento de um trajeto. [...] Trajeto é uma mensagem constituída por uma carga e dois limites (BACK; MATTOS, 1972, p. 533-534).

A noção de trajeto semântico será a noção básica para a análise semântica de todos os níveis de análise (cláusula, período, sentença, locução, vocábulo e morfema).

Tomemos a sentença "A fada transformou a moça de borralheira em princesa”.

A estrutura sintática dessa sentença é:

$\begin{array}{ccccc}\text { A fada } & \text { transformou } & \text { a moça } & \text { de borralheira } & \text { em princesa } \\ 1 & 2 & 3 & 8 \mathrm{X}^{8} & 8 \mathrm{Y}\end{array}$

Do ponto de vista do significado, temos nesta sentença uma carga (a moça) que sai de uma origem (borralheira) e chega a um destino (princesa). Temos, portanto, um trajeto.

O complemento sujeito (1) é denominado Assistente'. A locução verbal (sol da sentença) é denominada Fato.

Como elemento central da sentença, é o Fato que "organiza" o trajeto. Ele contém em si todo o trajeto e requisita complementos que manifestem os elementos desse trajeto. Assim, "transformar", o Fato da sentença, "contém em si e sugere: um transformador (assistente), um transformado (carga), um estado anterior (origem) e um estado posterior (destino)" (BACK; MATTOS, 1972, p. 554) ${ }^{10}$.

O exemplo acima teria a seguinte análise semântica ${ }^{11}$ :

$\begin{array}{ccccc}\text { A fada } & \text { transformou } & \text { a moça } & \text { de borralheira } & \text { em princesa } \\ \text { A } & \text { F } & \text { C } & \text { O } & \text { D }\end{array}$

Os constituintes da sentença (sol e complementos) podem, ainda, manifestar mais de um elemento do trajeto. Por exemplo, na sentença "Maria corou", na medida em que "corar" é passar de uma cor para outra, o Fato acumula (e impede sua manifestação por complementos) a origem e o des-

8 Desprezo a subclassificação dos complementos ablativos.

9 O ocupante do sujeito sempre está presente no trajeto, mas às vezes é origem, às vezes é destino, às vezes é carga e, às vezes, como no caso, é um agente que desencadeia o trajeto. Por isso, os autores identificam o sujeito com um papel semântico genérico a que denominam assistente.

10 o que me parece um bom modo de apresentar a noção tradicional de regência.

11 Onde $\mathrm{A}=$ assistente $\mathrm{F}=$ Fato $\mathrm{C}=$ carga $\mathrm{O}=$ origem $; \mathrm{D}=$ destino. 
tino; da mesma forma, "Maria" é assistente (por ser complemento sujeito) e carga. A análise semântica da sentença ficaria como abaixo:

$\begin{array}{cc}\text { Maria } & \text { corou } \\ \mathrm{A}(\mathrm{C}) & \mathrm{F}(\mathrm{OD})\end{array}$

Em todos os outros níveis de análise, os autores procuram identificar o trajeto semântico (com razoável grau de consistência, podemos dizer). Por exemplo, o vocábulo "acasalar" é entendido como "levar de unidades a casal" e o vocábulo "acertar" é entendido como "levar de errado a certo". o vocábulo "mortal" é entendido como "que tem a morte como destino" e "sapateiro" como "aquele que conserta sapatos". É preciso ter em mente que todos os outros níveis de análise, que não a cláusula, são obtidos a partir dela e que só nela é que têm existência.

\subsection{EstiLÍ́stica}

Finalmente, a última parte da Gramática é dedicada à Estilística.

Para os autores, a Estilística é o estudo dos procedimentos adotados pelos falantes para carregar de significado elementos da linguagem que, normalmente, não são significativos. Reproduzo aqui, resumidamente, um exemplo da Gramática (p. 721 e seguintes).

Alguém assiste a uma cena, tem uma situação à sua frente e deseja comunicá-la a um ouvinte. Vira-se para o ouvinte e diz: /o.'kak. to.tõ."bow.a.tra.ve."sa.do.na."”ru.a ${ }^{12}$ (o cacto tombou atravessado na rua).

A associação entre o texto do emissor e a situação permite que sejam identificados dois tipos de elementos: (a) elementos pares (elementos do texto que possuem correspondente na situação) e (b) elementos ímpares (elementos do texto sem correspondente na situação e elementos da situação sem correspondente no texto).

Para os autores, o processo estilístico consiste, basicamente, em tornar pares elementos ímpares.

Considerando a natureza do texto - a sentença "O cacto tombou atravessado na rua" é parte de um poema de Manuel Bandeira - podemos perceber que a escolha do texto pelo emissor permite que a sequência de sílabas /o.'kak.to.tõ."bow/, inicialmente ímpar, possa ser associada ao ruído que a queda do cacto deve ter feito na situação, ruído que era também

12 Na notação da LC, as aspas indicam intensidade: aspas simples indicam intensidade de vocábulo; aspas duplas indicam intensidade de locução; e aspas triplas indicam intensidade de sentença. 
um elemento ímpar (da situação). Da mesma forma, a presença de um pé quaternário no final da sentença /a.tra.ve."sa.do.na."'ru.a/ pode ser associada à posição final do cacto, que toma a rua de lado a lado (o ritmo é um elemento ímpar do texto e a posição final do cacto na rua é um elemento ímpar da situação). O gênio do poeta está justamente no talento de tornar pares elementos ímpares.

O restante da parte destinada à Estilística explora as possibilidades de aproveitamento estilístico de elementos ímpares em todos os níveis de análise.

Para encerrar, devo dizer que toda a teoria apresentada na Gramática vem acompanhada de abundante exemplificação, retirada na maior parte de poetas e prosadores brasileiros e portugueses. É notável, também, o caráter didático em que as apresentações da teoria são feitas.

\section{A RECEPÇÃo DA LC}

A reação da comunidade aos estudos de Back e Mattos quase nunca foi positiva. De forma geral, as propostas da LC foram recebidas friamente. o "inimigo" preferencial da LC era a gramática tradicional (a história de seu surgimento levava a isso: fazer uma nova descrição do português que viesse a substituir a descrição presente nas gramáticas escolares) e os gramáticos como sempre - simplesmente ignoraram suas propostas. Os linguistas, que estavam, à época, começando a ler os trabalhos de Chomsky, transferiram à LC as críticas que os gerativistas faziam aos estruturalistas americanos (postura coerente, se considerarmos as origens da LC e sua autocaracterização como uma "técnica descritiva").

Segundo Anthony Naro (1976),

O único grupo que, até agora, ousou fazer inovações dentro de uma orientação teórica foi o grupo liderado por Geraldo Mattos e Eurico Back, professores da Universidade Católica do Paraná em Curitiba (1972, 1973). Tendo como ponto de partida o enfoque tagmêmico, começaram fazendo ligeiras modificações e terminaram com um modelo que lhes pareceu suficientemente diferente da tagmêmica a ponto de merecer a nova denominação de "gramática construtural". Dizem eles: "Pretendemos ter alcançado uma sistematização completa, perfeita e coerente de todos os fatos da linguagem humana" (Back \& Mattos, 1973, p. 2). Embora esta, seguramente, seja uma das afirmações mais exageradas e carentes de base de todo o século, não se pode deixar de admirar o entusiasmo dos autores. Na realidade, a gramática construtural em nada ultra- 
passa suas origens estruturais, consistindo apenas de um método essencialmente taxonômico de descrição lingüística (mais do que de explicação) estreitamente baseada na análise de constituintes imediatos. Uma análise construtural típica consiste em sublinhar num texto os seus principais constituintes e enumerá-los com índices arbitrários de acordo com funções sintáticas que não chegam a ser definidas. Vejamos um exemplo muito simples (1972, p. 184):

$$
\begin{array}{ccc}
\text { Aquele homem } & \text { viu } & \text { meninos } \\
1 & 2 & 3
\end{array}
$$

Os ocupantes dessas funções são reconhecidos por meio de critérios paradigmáticos (os ocupantes de /2/ são conjugados, etc.). Há algumas novidades terminológicas pitorescas (o núcleo de um constituinte é batizado de "sol", enquanto que os elementos dependentes são os "planetas"), mas em geral é conservada a maioria dos erros característicos do estruturalismo, inclusive a concepção behaviorista básica que considera a língua como uma reação a um estímulo. Os autores, aliás, não parecem estar completamente familiarizados com, ou melhor, não parecem compreender as principais correntes da lingüística moderna, como se depreende de seu comentário sobre a "maior insistência na performance do que na competence dada pelo transformacionalismo (1973, p. 114; as palavras-chave aparecem em inglês no texto) como também sobre o "desprezo da semântica" pelo estruturalismo (p. 113). A primeira dessas observações representa exatamente o oposto da verdade, enquanto a segunda não é menos surpreendente diante do fato de que todo o trabalho de semântica realizado no Brasil tem sido estritamente estrutural. Será possível que notícias do trabalho realizado em São Paulo não tenham chegado ao estado limítrofe do Paraná?

Mesmo que as verdadeiras realizações do construturalismo não sejam grandes e que a escola tenha a oferecer poucos avanços teóricos, o nascimento desse tipo de movimento no Brasil é de grande importância por duas razões: primeiro, o fato de que finalmente os linguistas brasileiros tenham, pelo menos em um caso, ousado trilhar um caminho original pode ajudar a criar um ambiente que leve à indagação crítica e ao desenvolvimento intelectual. Em segundo lugar, temos o fato de que a principal obra daquela escola, os dois volumes da Gramática construtural da língua portuguesa, representa uma contribuição importante à lingüística do português. Abundantemente documentada, suas principais características residem numa franca adesão ao uso real como base de descrição no lugar de alguma norma imaginada ou desejada, e no uso explícito da argumentação com exemplos e contra-exemplos a fim de estabelecer as análises ou classificações (ver também Back 1973 para uma argumentação explícita em fonêmica taxonômica). Este segundo ponto é especialmente importante em vista da tendência corrente no Brasil, já anteriormente por nós observada, de substituir a argumentação lingüística por um formalismo estéril (NARO, 1976, p. 95-96). 
Naro exemplifica bem o tipo de reação que a comunidade teve diante das propostas da LC, embora a ressalva que faz sobre os méritos da "ousadia" e sobre a contribuição descritiva da Gramática não seja comum. A opinião mais comum sobre a LC no seio da comunidade científica da época é representada na seguinte afirmação que encontramos em Altman (1998), feita, certamente, por alguém que frequentou o curso de especialização da UnB na mesma época que Back ${ }^{13}$ :

Eurico Back fez o curso e ficou famoso por ter sido o único capaz de ler Bloomfield de ponta a ponta. Não havia traduções e nem todos podiam ler em inglês. Mais tarde, Back reinventou a lingüística. Fez uma cópia da Tagmêmica e da psicolingüística behaviorista de Bloomfield. O "construturalismo" nasceu dessas leituras (ALTMAN, 1998, p. 117, grifo nosso).

É interessante, também, o tipo de leitura que Cristina Altman faz do movimento construturalista, assumindo a perspectiva historiográfica. Em suas palavras:

Num certo sentido, o construturalismo de Back \& Mattos foi visto, neste contexto, como exceção a esta atitude que Naro considerou típica ["o pesquisador escolhe [...] um embasamento teórico para aplicá-lo ao estudo de determinada área da gramática portuguesa, sem dar-se ao trabalho de indagar sobre a adequação do próprio arcabouço teórico". Naro, 1976: 95]. A fugaz, mas forte, repercussão do modelo construtural na primeira metade da década de setenta poderia ser eventualmente objeto de um estudo de caso mais aprofundado, sobretudo do ponto de vista da correlação entre as novas idéias que estavam surgindo face ao clima dominante de opinião da época. Nas páginas finais do manifesto de 1973 (CONSTRUTURA, 1:1, 112-115), Back e Mattos dispõem, em forma de lista, o que consideram as principais características do construturalismo (em oposição aos então chamados "estruturalismo" e "transformacionalismo"). Dentre elas: o método, que deve ser dedutivo; a metalinguagem; o reconhecimento de níveis de análise superiores à sentença (diálogo, cláusula, período, sentença); uma nova divisão entre os componentes da Gramática (Fonologia, Morfologia e Sintaxe); a inclusão da Fonética, Vocabulário, Semântica e Estilística na Lingüística e o estabelecimento de universais lingüísticos.

As características citadas dificilmente poderiam ser consideradas originais, mesmo no estágio em que se encontravam as propostas estruturalistas e/ou transformacionalistas em evidência na épo- 
ca. Embora se lhes tenham reconhecido o mérito da tentativa (v. Naro 1976), o modelo, enquanto tal, foi rejeitado pelo restante da comunidade acadêmica que o percebeu fortemente vinculado a princípios estruturalistas (tagmêmicos), incompatíveis com o novo ideal de cientificidade gerativista (chomskiano) que começava a entrar em evidência.

Seja como for, o fato é que o movimento foi proposto como original. Nascido no Paraná, longe, portanto, dos principais eixos de divulgação - Rio e São Paulo - mesmo assim conseguiu criar seus próprios meios de divulgação, o que parece reforçar a hipótese de que o sucesso na aceitação de um conjunto de idéias parece depender mais da capacidade dos seus organizadores de constituírem grupos e obterem commitment, do que do valor intrínseco dessas mesmas idéias. Ainda que a apresentação e aplicação das proposições do modelo tenham se limitado, na minha amostra, aos dois artigos de Mattos na RBL (Mattos 1974: 22-39 e 1976: 59-76), é preciso lembrar que o construturalismo teve repercussão suficiente para manter um periódico durante vários anos, publicar uma gramática e também ser alvo de críticas (cf. Istre 1975), principal índice do seu efêmero sucesso (ALTMAN, 1998, p. 281-282).

Uma das características da LC contribuiu muito para que a comunidade dos linguistas a ignorasse: a terminologia. Cientes de que o empréstimo de termos de outras teorias traz consigo o risco de que as noções associadas aos termos venham junto, Back e Mattos procuraram criar termos novos para noções novas e procuraram definir cuidadosamente usos novos de termos emprestados. Com isso, o esforço para compreender o que era dito aumentou enormemente. Se associarmos a percepção de que se tratava "apenas" de outra proposta estruturalista com a dificuldade de entender o que a teoria propunha, temos um obstáculo imenso para a boa vontade dos linguistas em aceitar a LC.

Da mesma forma, uma certa arrogância por parte dos autores nas várias apresentações que fizeram em congressos e seminários, contribuiu para que a má vontade com relação à LC se disseminasse. Afirmações como a que Naro, no trecho citado acima, qualifica como "uma das afirmações mais exageradas e carentes de base de todo o século" - a afirmação de que "Pretendemos ter alcançado uma sistematização completa, perfeita e coerente de todos os fatos da linguagem humana" (Back; Mattos, 1973, p. 2) - certamente não contribuíram para que a LC fosse considerada pela comunidade. Há relatos de que, ao final de uma apresentação de Geraldo Mattos num encontro de linguistas, Francisco da Silva Borba teria levantado e dito: "Colegas, podemos ir para casa. Todos os problemas da linguística já foram resolvidos pelo professor Geraldo".

Provavelmente, outro empecilho para a divulgação da LC no meio universitário brasileiro foi o fato de que a grande maioria das publicações da 
LC saiu pela editora FTD, editora majoritariamente voltada para as escolas de ensino fundamental e médio e com pouca inserção nas universidades.

Não obstante, sem muito medo de errar, posso dizer que a LC foi uma teoria linguística inovadora, no contexto das teorias estruturalistas (uma "técnica de descrição" inovadora se comparada com outras técnicas existentes à época $)^{14}$. E minha hipótese de trabalho é a de que a "forte repercussão" de que nos fala Altman se dá, primordialmente, nos círculos estruturalistas (em outras palavras, a LC repercute, de forma positiva, entre os linguistas que já assumiam uma perspectiva estruturalista).

Enfim, mais do que uma causa singular, um conjunto de fatores internos e externos à proposta da LC determinou o baixo impacto obtido entre os linguistas. Fatores "sociológicos" limitaram, certamente, o interesse da comunidade: o fato de ser produzida fora dos grandes centros de produção acadêmica (Rio de Janeiro e São Paulo) e ter sua publicação feita por uma editora com pouco acesso aos meios universitários; o fato de ser sido divulgada pelos autores numa postura discursiva "arrogante”, provocativa. Por outro lado, fatores internos, como a dificuldade de acesso às propostas da LC em virtude do hermetismo terminológico e a fácil e clara identificação com as propostas estruturalistas diminuíram muito o interesse dos linguistas em investir esforços no entendimento das propostas teóricas apresentadas.

Alguns comentaristas atribuem esse baixo impacto basicamente à concorrência com o gerativismo, que começava a ser implantado no Brasil. É o caso de Paulino Vandresen (2001), que afirma:

Em termos de teorias lingüísticas, nos primeiros anos, predominou o estruturalismo, seguindo modelos americanos como Bloomfield, Sapir e Pike, ou europeus como a Escola de Praga, Martinet, Pottier etc. Tivemos até um modelo teórico próprio, batizado como "lingüística construtural", proposto por Eurico Back e Geraldo Mattos, de Curitiba, divulgado na revista Construtura, e que teve como resultado de suas pesquisas uma Gramática Construtural da Língua Portuguesa (2 volumes), publicada em 1972 pela editora FTD, de São Paulo. A proposta construtural surgiu no momento da implantação dos cursos de pós-graduação, e não resistiu à concorrência do modelo gerativista que dominou a década de 70 , graças aos novos doutores que retornavam do exterior (A LÍNGÜISTICA NO BRASIL, Disponível em: < http://www.comcien-

14 É o que se depreende da afirmação de Naro, de que a Gramática Construtural "representa uma contribuição importante à lingüística do português". Por outro lado, a afirmação de que "a gramática construtural em nada ultrapassa suas origens estruturais, consistindo apenas de um método essencialmente taxonômico de descrição lingüística (mais do que de explicação) estreitamente baseada na análise de constituintes imediatos" mostra que Naro avalia a LC fora do contexto estruturalista que é seu nicho próprio. 
cia.br/reportagens/linguagem/ling15.htm > . Acesso em: 3/3/2014, grifo nosso).

Esse, certamente, é um fator a ser levado em conta - como já fizemos, acima - e acredito que seja um fator com bastante peso, mas não creio que seja o único fator determinante do baixo interesse da comunidade pela $\mathrm{LC}^{15}$.

Em apoio à conclusão de que houve outros fatores em jogo na avaliação negativa da LC, creio que podemos levar em conta a posição de Landon Lockett, professor na Universidade do Texas (Austin), autor da única resenha da Gramática Construtural feita no exterior que consegui localizar (ver LOCKETT, 1974). Segundo ele,

For reasons not completely explained (a page is missing from the introduction) the authors of this work have devised their own descriptive model for language, and applied it to produce this Gramática Construtural of Portuguese [...]

Working through these two volumes was, for this reviewer at least, a troublesome and at times baffling experience. First, the authors' unique descriptive model, in all its classificatory and terminological complexity, is presented as though it were established truth, with very little indication of why it was devised, or why a particular analysis is chosen to deal with some particular problem. [...] Still another difficulty arises from the authors' confessed "desprezo da nomenclatura vigente." Given the present level of uncertainty in descriptive methodology, surely any linguist can be forgiven for devising new terminology, when necessary. However, aside from probably abusing this prerogative, these authors add considerably to the reader's difficulties by their practice of giving (without any apparent justification) new or drastically altered meanings to words that already have a well established usage. [...]

The reader who, whether or not enthused about the authors' methodological approach, looks for something new in the description of Portuguese will be largely disappointed (LOCKETT, 1974, p. 392-393).

Aparentemente, o foco da resenha de Lockett está nas dificuldades que a inovação terminológica traz para a leitura da Gramática Construtu-

15 Posso apresentar um depoimento pessoal. Em 1976, cursando o mestrado na Unicamp, procurei Carlos Franchi para definir meu projeto de dissertação. Com uma grande dose de ingenuidade, apresentei um projeto em que faria uma comparação entre a LC e a Gramática Gerativa. O projeto foi liminarmente recusado, com a alegação de que poderia ser desenvolvido, mas com algum outro orientador. Acabei trabalhando com adjetivos no quadro de uma semântica formal. 
ral, assim como a falta de justificativa para as inovações teóricas. É de se destacar, também, que em nenhum momento Lockett avalia a LC à luz do gerativismo, mas sempre a considera no conjunto dos modelos descritivos estruturalistas.

A questão central talvez seja a de saber se alguma teoria nascida no Brasil teria a possibilidade de se tornar um paradigma dominante no país. A resposta - difícil - provavelmente seria um não. Já escrevi algo sobre isso num texto de mesa-redonda no Congresso da Abralin de 1986, que intitulei "Linguística no Brasil: mera importação de modelos estrangeiros?" (ver BORGES NETO, 1986), texto em que caracterizava a linguística no Brasil como uma linguística "de consumo", em que a produção (teórica ou descritiva) era sempre relegada a um segundo plano.

Posso dizer também que a LC se apresentou - no discurso de seus autores - como um projeto destinado não só a revolucionar o tratamento dos fatos linguísticos, olhando-os de um novo ponto de vista, mas como um projeto que, no fundo, tinha sempre o olhar do professor de português, interessado em obter também uma revolução no ensino do português como língua materna.

\section{CONCLUSÃo}

O fim do século XX e os primeiros anos do século XXI veem surgir, ao lado das reedições de gramáticas mais antigas, uma série de gramáticas com novas orientações teóricas. Estou pensando aqui em trabalhos como a Gramática do Português Falado, com oito volumes, escrita por uma extensa equipe de linguistas (CASTILHO, 1990, 1993; ILARI, 1992; CASTILHO; BASÍLIO, 1996; KATO, 1996; KOCH, 1996; NEVES, 1999; ABAURRE; RODRIGUES, 2002) ${ }^{16}$, na Gramática Descritiva do Português de Mario Perini (PERINI, 1995), na Gramática de Usos do Português, escrita por Maria Helena de Moura Neves (NEVES, 2000), na Gramática do Português Culto Falado no Brasil, também escrita coletivamente por uma equipe de linguistas, com três volumes já publicados (JUBRAN; KOCH, 2006; ILARI; NEVES, 2008; KATO; NASCIMENTO, 2009) e outros dois no prelo (RODRIGUES; ALVES; e ABAURRE), na Nova Gramática do Português Brasileiro de Ataliba de Castilho (CASTILHO, 2010), na Gramática do Português Brasileiro de Mário Perini (PERINI, 2010) e na Gramática Pedagógica do Português Brasileiro de Marcos Bagno (BAGNO, 2011).

16 As entradas indicam os organizadores e as datas de publicação. 
Suponho que os teóricos do texto não veriam problemas se eu afirmasse que "gramática" se trata de um gênero textual, com características formais e substantivas mais ou menos bem delimitadas.

Essas gramáticas não têm, em princípio, o caráter normativo (embora, uma "gramática pedagógica", por exemplo, não possa evitar o viés normativo). Nem ficam completamente presas na teia teórica criada pelos primeiros gramáticos da antiguidade clássica. Abertas para os descobrimentos da moderna teoria linguística, mesclam perspectivas teóricas com a finalidade de melhor descrever e explicar os fenômenos linguísticos do português contemporâneo.

A Gramática Construtural da Língua Portuguesa poderia ser incluída nesta lista. Mais ainda, poderia ser considerada pioneira desse "movimento" de renovação das gramáticas. Sem o ranço normativo das gramáticas escolares (a questão da variação linguística é sempre levada em consideração, embora o tratamento dado a ela nem sempre seja satisfatório), a Gramática Construtural claramente pertence ao gênero textual das "gramáticas" e sua teoria de fundo não só se afasta decisivamente da teoria gramatical greco-latina, como se afasta também da grande maioria das teorias linguísticas do século XX. A Gramática Construtural é resultado de uma elaboração teórica original, que se desenvolveu sobre a análise empírica dos fenômenos da língua portuguesa - é uma gramática descritiva do português que se fez teoria linguística ${ }^{17}$.

Independente dos méritos que uma tal teoria possa ter (o risco de errar numa tentativa pioneira é sempre muito grande), a Gramática Construtural não pode ser ignorada pelos linguistas - ao menos pelos linguistas que se interessam pela história de nossa disciplina no Brasil.

\section{REFERÊNCIAS}

A LÍNGÜÍSTICA NO BRASIL, Disponível em: < http://www.comciencia.br/reportagens/linguagem/ ling15.htm>. Acesso em: 3/3/2014.

ABAURRE, Maria Bernadete (Org.). Gramática do Português Culto Falado no Brasil, Vol. IV. No prelo.

ABAURRE, Maria Bernadete; RODRIGUES, Ângela C. S. (Orgs.). Gramática do Português Falado. Vol. VIII: novos estudos descritivos. Campinas: Editora da Unicamp/FAPESP, 2002.

ALTMAN, Cristina. A Pesquisa Lingüística no Brasil: 1968-1988. 1. ed. São Paulo: Humanitas, 1998.

17 Não se trata da aplicação de uma teoria preexistente aos dados do português, mas de uma teoria que surge da análise empírica desses dados. 
BACK, E. São fonemas as vogais nasais do português? Construtura, Curitiba, v. 1, n. 2, p. 297-317, 1973.

BACK, E.; MATTOS, G. Gramática Construtural da Língua Portuguesa. 2 v. São Paulo: FTD, 1972. 1973. Lingüística Construtural: manifesto. Construtura, Curitiba, v. 1, n. 1, p. 1-129,

BAGNO, Marcos. Gramática Pedagógica do Português Brasileiro. São Paulo: Parábola, 2011.

BORGES NETO, J. Linguística no Brasil: mera importação de modelos estrangeiros? ABRALIN - Boletim da Associação Brasileira de Linguística n. 8, 1986. p. 77-82.

CAMARA JR., J. M. O estruturalismo lingüístico. Tempo Brasileiro, Rio de Janeiro, n. 15/16, p. 5-43, 1967.

CASTILHO, Ataliba Teixeira de. (Org.). Gramática do Português Falado. Vol. I: a ordem. Campinas: Editora da Unicamp: FAPESP, 1990.

. (Org.). 1993. Gramática do Português Falado. Vol. III: as abordagens. Campinas: Editora da Unicamp: FAPESP, 1993.

. Nova Gramática do Português Brasileiro. São Paulo: Contexto, 2010.

CASTILHO, Ataliba Teixeira de; BASílio, Margarida (Orgs.). Gramática do Português Falado. Vol. IV: estudos descritivos. Campinas: Editora da Unicamp: FAPESP, 1996.

ILARI, Rodolfo. (Org.). Gramática do Português Falado. Vol. II: níveis de análise. Campinas: Editora da Unicamp, 1992.

ILARI, Rodolfo; NEVES, Maria Helena de Moura (Orgs.). Gramática do Português Culto Falado no Brasil, Vol. II: classes de palavras e processos de construção. Campinas: Editora da Unicamp, 2008.

JUBRAN, Célia; KOCH, Ingedore (Orgs.). Gramática do Português Culto Falado no Brasil, Vol. I: construção do texto falado. Campinas: Editora da Unicamp, 2006.

KATO, Mary (Org.). Gramática do Português Falado. Vol. V. Campinas: Editora da Unicamp: FAPESP, 1996.

KATO, Mary; NASCIMENTO, Milton do (Orgs.). Gramática do português culto falado no Brasil, Vol. III - a construção da sentença. Campinas: Editora da Unicamp, 2009.

KOCH, Ingedore (Org.). Gramática do Português Falado. Vol. VI. Campinas: Editora da Unicamp: FAPESP, 1996.

LOCKETT, Landon. Review of Gramática Construtural da Língua Portuguesa by Eurico Back; Geraldo Mattos. Hispania, v. 57, n. 2, p. 392-393, May 1974. Disponível em: <http://www.jstor. org/stable/339869>, Acesso em: 20/7/2009.

MATTOS, G.; BACK, E. Prática de Ensino da Língua Portuguesa. São Paulo: FTD, 1974.

NARO, A. J. (Org.). Tendências Atuais da Lingüística e da Filologia no Brasil. Rio de Janeiro: Francisco Alves, 1976.

NEVES, Maria Helena de Moura (Org.). Gramática do Português Falado. Vol. VII. Campinas: Editora da Unicamp: Humanitas, 1999.

Gramática de usos do português. São Paulo: Editora da UNESP, 2000.

PERINI, Mário A. Gramática Descritiva do Português. São Paulo: Ática, 1995.

Gramática do Português Brasileiro. São Paulo: Parábola, 2010. 
BORGES NETO, J. A Linguística Construtural: um capítulo da históRIA dA Linguística no Brasil

RODRIGUES, Ângela C. S.; ALVES, Ieda Maria; ABAURRE, Maria Bernadete (Orgs.). Gramática do Português Culto Falado no Brasil, Vol. V. No prelo.

UCHOA, Carlos E. F. Os estudos e a carreira de Joaquim Mattoso Camara Jr. In: CAMARA JR., J. M. Dispersos. Rio de Janeiro: FGV, 1975. p. VII-XX.

Submetido em: 24/05/2013

Aceito em: 18/07/2013 